Cite this: RSC Adv., 2014, 4, 19970

Received 6th December 2013

Accepted 15th April 2014

DOI: $10.1039 / \mathrm{c} 4 \mathrm{ra02928c}$

www.rsc.org/advances

\section{Long-term activity of biohybrid coatings of atrazine-degrading bacteria Pseudomonas sp. ADP†}

\author{
A. Pannier, ${ }^{\star a}$ T. Lehrer, ${ }^{\text {b M. Vogel, }}{ }^{\text {cd }}$ U. Soltmann, ${ }^{a}$ H. Böttcher, ${ }^{\text {a } S . ~ T a r r e, ~}{ }^{\text {b }}$ M. Green, ${ }^{\text {b }}$ \\ J. Raff ${ }^{\text {d }}$ and K. Pollmann ${ }^{\text {d }}$
}

The atrazine-degrading bacterial strain Pseudomonas sp. ADP was immobilized by the sol-gel process within thin silica layers coated onto water-retaining carrier materials (expanded clay pellets and scoria). The performance of the obtained biohybrid material has been investigated concerning long-term activity under non-growth conditions. Experiments were run in phosphate buffer containing atrazine (20 mg $\mathrm{l}^{-1}$ ) as the sole source of carbon and nitrogen. Even after one year of consecutive batch tests, P. ADP immobilized onto expanded clay pellets showed a high atrazine degradation activity. In the course of long-term batch experiments, the average amount of removed atrazine was about $94 \%$ during each assay cycle. Staining with CTC revealed that in spite of cultivation under non-growth conditions over a period of one year, immobilized cells were still vital and showed respiratory activity.

\section{Introduction}

Biohybrid materials consisting of inorganic oxide matrices and integrated biomolecules (e.g., enzymes) or living cells are of special interest for bioremediation purposes due to the combination of a stable matrix system with a high bioactivity. In the last few decades, there have been huge improvements in the development of immobilization techniques based on sol-gel processes to produce bioactive ceramic-like silica matrices. By avoiding critical preparation conditions that would lead to denaturation of the biocomponents (e.g., extreme pH-values, high levels of organic solvent, high temperatures) even living cells can be embedded by recent sol-gel processes. Usually neutralized and mainly aqueous silica sols which contain only small amounts of organic solvents are used for cell immobilization. Due to neutralization of the "sol", which is a colloidal dispersion of silica nanoparticles, the polymerization reaction (condensation) of the nanoparticles is triggered, resulting in the formation of a "gel". The overall process is therefore commonly

${ }^{a} G M B U$ e.V., Department of Functional Coatings, Bautzner Landstrasse 45, D-01317 Dresden, Germany. E-mail: pannier@gmbu.de; Fax: +49 351 2695341; Tel: +49 351 2695342

${ }^{b}$ Technion, Israel Institute of Technology, Technion city, Faculty of Civil and Environmental Engineering, Haifa 32000, Israel

${ }^{c}$ Helmholtz-Zentrum Dresden-Rossendorf, Institute of Resource Ecology, Bautzner Landstrasse 400, D-01328 Dresden, Germany

${ }^{d}$ Helmholtz-Zentrum Dresden-Rossendorf, Helmholtz Institute Freiberg for Resource Technology, Bautzner Landstrasse 400, D-01328 Dresden, Germany

$\dagger$ This article is dedicated to the $65^{\text {th }}$ anniversary of Professor Avnir. He is one of the pioneers who used the sol-gel technology to immobilize biomaterials such as enzymes and living cells within inorganic matrices. called the "sol-gel process". ${ }^{1}$ During sol-gel transition, admixed cells are immobilized within the forming three-dimensional inorganic network.

A wide diversity of methods is available to shape silica matrices. The silica sols can be cast into molds and subsequently gelled to form shaped silica gel bodies, or they can be deposited as thin silica layers onto various carrier substrates (e.g., glass, metal, textiles, plastics) using conventional coating techniques like dip or spin coating.

First attempts to immobilize biomolecules like enzymes by sol-gel techniques date from the 50's. ${ }^{2}$ In the eighties, Glad et $a .^{3}{ }^{3}$ immobilized yeast cells in aminopropylsilane-derived solgel matrices. However, the viability and bioactivity of the embedded cells were not investigated. In the late eighties and early nineties, Carturan et $a .^{4}{ }^{4}$ demonstrated that Saccharomyces cerevisiae yeast cells retained their bioactivity within a sol-gel silicate matrix. Avnir and his colleges considerably advanced the development of sol-gel derived biomaterials by their investigations of different biomaterials. ${ }^{5,6}$ They described the properties of various enzymes immobilized within tetramethoxysilane (TMOS) based sol-gel matrices. Since then, the pioneering procedure was extended rapidly to antibodies, nucleic acids, phospholipids, polysaccharides and also living cells. ${ }^{7}$ Immobilization procedures using milder conditions have been found, permitting efficient cell encapsulation within sol-gel-derived matrices by maintaining cell viability. ${ }^{\mathbf{1} 8-11}$ A large variety of cells such as bacteria, fungi, microalgae, lichens, plant cells, and even animal cells has been trapped within silica matrices. The application of sol-gel immobilized cells have been investigated for environmental remediation purposes, medicine as well as other areas of biotechnology. ${ }^{7,11-15}$ However, it has been shown 
that the maintenance of long-term viability and activity is crucial. ${ }^{\mathbf{1 1 6 , 1 7}}$ A major factor to maintain immobilized cells alive is related to the preservation of humidity within the silica matrix. This problem is particularly decisive for thin films as they are extremely susceptible to fast drying out. Besides the addition of matrix softener and water-retaining substances within the silica matrix, such as polyols and sugars, ${ }^{7,18}$ the use of carrier materials possessing high water storage properties such as expanded clay pellets present a promising approach to prevent excessive drying of the entrapped cells. For instance, the bacterial strain Aquincola tertiaricarbonis, which is able to degrade the fuel oxygenate methyl tert-butyl ether (MTBE), has been immobilized within thin silica layers coated onto expanded clay pellets. Immobilized cells could be easily stored out of liquid under humid atmosphere. Even after 8 months of storage at $25^{\circ} \mathrm{C}, A$. tertiaricarbonis cells showed no significant reduction of their metabolic activity and MTBE was easily biodegraded. ${ }^{19}$

Like the recalcitrant pollutant MTBE, the efficient removal of residues of the $s$-triazine herbicide atrazine in environmental soil and water is of considerable interest. Significant amounts of atrazine have been found worldwide in ground water due to nonpoint source pollution from agricultural activities with concentrations up to $1000 \mu \mathrm{g} \mathrm{l^{-1 } , \mathbf { 2 0 }}$ clearly exceeding admissible concentrations (e.g., $0.1 \mu \mathrm{g} \mathrm{l^{-1 }}$ in the EU). ${ }^{21}$ Moreover, up to $22 \mathrm{mg} \mathrm{l}^{-1}$ of atrazine residues were found in well water due to point source pollution near herbicide mixing/loading facilities. ${ }^{22}$

In 2004, atrazine was banned in the EU, however, it is still widely used in the USA. Conventional technologies for the removal of atrazine from surface and groundwater such as ozonation and adsorption onto activated carbon are efficient but often expensive. ${ }^{23,24}$ An alternative to physical and chemical techniques is the biological degradation of atrazine by microorganisms. Different atrazine-degrading bacteria and fungi have so far been isolated from contaminated sites, with Pseudomonas sp. ADP ( $P$. ADP) being one of the fastest atrazinedegrading bacterial strains. Its degradation rates are higher by several orders of magnitude compared to other strains. ${ }^{25}$ Furthermore, $P$. ADP rapidly mineralizes atrazine under aerobic and denitrifying conditions as well as under non-growth conditions while leaving no toxic metabolites. ${ }^{25-27}$ Atrazine is completely degraded to ammonia $\left(\mathrm{NH}_{4}^{+}\right)$and $\mathrm{CO}_{2}$.

To use the capability of atrazine-degrading microorganisms for remediation, the cells have to be prevented from being washed out as well as protected from suppression by other strains. Prior cell immobilization could therefore be advantageous as shown by Siripattanakul et al. ${ }^{28}$ who investigated the performance of atrazine-degrading bacteria in field studies. Cell loss from in phosphorylated-polyvinyl alcohol (PPVA) immobilized cells was 10-100 folds lower compared to free cell systems. Furthermore, immobilization provides protection to some extend from high shear forces as well as detrimental effects of the surrounding medium such as $\mathrm{pH}$ and toxic substances. Protected within the immobilization matrix, embedded cells may thus be able to overcome numerous changing conditions in soils and waterways and may be released after adaptation to prevailing environmental conditions. ${ }^{29}$ Additionally, the handling of immobilized cells is much easier for cell recovery and separation.
Several methods can be applied for whole-cell immobilization such as flocculation, attachment onto support materials, cross-linking of cells, as well as encapsulation within an organic or inorganic matrix. Advantages and disadvantages of different immobilization techniques have been addressed in several reviews. ${ }^{29-33}$ A suitable immobilization matrix for environmental applications should ensure a stable, long-term activity of the immobilized cells. Furthermore, it should possess a good mechanical stability and withstand high water flow. A high amount of viable and active cells should be maintained within the immobilization matrix without significant release during operation. The immobilization procedure should be cost effective for large-scale applications.

Additionally, it would be advantageous if the immobilized cells could be stored out of liquid by only minimal loss of viability and activity. This will reduce costs for storage and transport, and further simplifying handling of the immobilized cells. Immobilization by the sol-gel process onto carrier materials possessing high water-retaining capabilities could therefore be an interesting approach.

In the present study, $P$. ADP has been immobilized by the sol-gel process within pure silica hydrogels as well as within thin silica layers coated onto two different carrier materials (expanded clay pellets and scoria) to ensure a good preservation of humidity within the silica matrix. By studying the biodegradation of atrazine over a period of more than one year, the longterm stability of the immobilized cells has been surveyed during consecutive operation under non-growth conditions with atrazine as sole source of carbon and nitrogen. Furthermore, the performance of immobilized $P$. ADP has been investigated after storage, as $A$. tertiaricarbonis immobilized within thin silica layers onto expanded clay showed surpassing storage stability when stored out of liquid. ${ }^{19}$

\section{Experimental}

\section{Materials}

Scoria was supplied grounded by Tuff Enterprises (Merom Golan, Israel) with a grain size ranging from 1-2 mm. Expanded clay pellets (diameter 10 to $20 \mathrm{~mm}$ ) were provided by AMykor $\mathrm{GmbH}$ (Germany). They were mechanically crushed and sieved to obtain granules of a diameter of about 1-2 mm. Subsequent, the granules were thoroughly washed and dried. The silica alkoxide precursor tetraethoxysilane (TEOS) was obtained from Wacker Chemie GmbH (Germany). GLYEO (3-glycidyloxypropyl-triethoxysilane) were purchased from Fluka. Atrazine (2-chloro-4-ethylamine-6isopropylamino-s-triazine, 94\% technical grade) was kindly supplied by Agan Chemicals (Ashdod, Israel). The intermediate of atrazine degradation hydroxyatrazine (2-hydroxy-4-ethylamino-6isopropylamino-s-triazine) was purchased from Fluka.

\section{Bacterial strain and culture conditions}

The bacterial strain Pseudomonas sp. ADP (PubMed ID 47660) used was kindly supplied by Mandelbaum who isolated that strain in 1995 from an atrazine spill site. ${ }^{25}$ 
$P$. ADP was routinely grown on atrazine agar medium at $30{ }^{\circ} \mathrm{C}$ for 3-4 days and in atrazine liquid growth medium at $30{ }^{\circ} \mathrm{C}$ as described by Klein et al. ${ }^{34}$ Growth media were prepared according to Mandelbaum et al. ${ }^{35}$ and contained $0.2 \%$ (wt/vol) sodium citrate as the carbon source and atrazine as the only nitrogen source at concentration of either $20 \mathrm{mg} \mathrm{l}^{-1}$ (liquid medium) or $150 \mathrm{mg} \mathrm{l}^{-1}$ (agar medium).

For cell immobilization, cells were first cultured in atrazine liquid medium containing $20 \mathrm{mg} \mathrm{l}^{-1}$ atrazine for three days at $30{ }^{\circ} \mathrm{C}$ under agitation (100 rpm). Subsequently, cells were transferred to Luria broth (LB) medium according to Miller (1972) for overnight growth at $30^{\circ} \mathrm{C}$. Cells were harvested by centrifugation $(10000 \mathrm{~g}, 15 \mathrm{~min})$ and washed with phosphate buffer (20 mM, pH 7.4). Subsequently, cells were resuspended in phosphate buffer to a concentration of bacterial dry matter (bdm) of approximately $0.05 \mathrm{~g}$ bdm per $\mathrm{ml}$ prior to further use for immobilization.

\section{Synthesis of silica nanosols}

Synthesis of silica nanosol A for coatings. The silica alkoxide precursor tetraethoxysilane (TEOS) was mixed with de-ionized water and $0.01 \mathrm{M} \mathrm{HCl}$ in a ratio of $1: 6: 3$. The mixture was stirred overnight at room temperature to ensure hydrolysis resulting in an acidic silica nanosol with approximately $3.4 \mathrm{wt} \%$ solid content. Formed alcohol during alkoxide hydrolysis was removed by evaporation overnight. The obtained silica nanosol was stored at $4{ }^{\circ} \mathrm{C}$ until immobilization. The nanosol was stable for several months.

Synthesis of silica nanosol B for hydrogels. For cell immobilization within silica hydrogels, a silica nanosol possessing a higher solid content has been synthesized in order to improve the stability of the resulting hydrogel. Furthermore, GLYEO was added as a cross-linking agent. TEOS was mixed with GLYEO, de-ionized water and $0.01 \mathrm{M} \mathrm{HCl}$ in a ratio of $3: 3: 1: 3$. The mixture was stirred overnight resulting in a silica nanosol with approximately $15 \mathrm{wt} \%$ solid content. After alcohol evaporation, silica nanosol was stored at $4{ }^{\circ} \mathrm{C}$. The nanosol was stable for about three weeks.

\section{Immobilization procedures}

Immobilization within thin silica layers coated onto carrier materials. The silica nanosol A consisting of about $3.4 \%$ silica content was neutralized using $1 \mathrm{~N} \mathrm{NaOH}$ to trigger the condensation reaction. Subsequently, the bacteria suspension was mixed to the neutralized sol resulting in a cell density of about $5 \mathrm{~g}$ bdm per l. Cells were immobilized at the surface of expanded clay or scoria particles by immersion of the carrier materials into the cell-sol suspension for $5 \mathrm{~min}$. Subsequently the carrier materials were removed and excess cell-sol suspension dripped off. The coated carrier materials were stored in a humid chamber for gelling. The volume of the residue of the cell-sol suspension was measured and used for the calculation of adsorbed sol and percentage of immobilized $P$. ADP. The bacterial loading was about $3.6 \mathrm{~g}$ bdm per $\mathrm{kg}$ (corresponding to $1.9 \mathrm{~g} \mathrm{bdm}$ per l) for expanded clay and $1.8 \mathrm{~g}$ bdm per kg (corresponding to $1.6 \mathrm{~g}$ bdm per l) for scoria, respectively. Samples were stored under moist conditions at $4{ }^{\circ} \mathrm{C}$ prior to atrazine degradation experiments.

Immobilization within silica hydrogels. Pure silica hydrogels containing $P$. ADP were prepared using the silica nanosol B with about $15 \%$ silica content. Bacteria suspension was mixed to the sol prior to neutralization because gelation of the nanosol starts immediately after neutralization. The bacteria-sol suspension (4.2 g bdm per l) was cast into Petri-dishes and was subsequently neutralized using $1 \mathrm{~N} \mathrm{NaOH}$. After gelation for about 1 $\mathrm{h}$, the gel was cut with a scalpel into small cubes and left for further gelling for $2 \mathrm{~h}$. Samples were stored under moist atmosphere at $4{ }^{\circ} \mathrm{C}$ prior to use.

\section{Characterization of the immobilization matrix}

Two different carrier materials were used for immobilization experiments (1) expanded clay and (2) scoria possessing a grain size of about 1-2 mm. For determination of porosity and water uptake capacity, samples were oven dried to a constant weight at $120{ }^{\circ} \mathrm{C}$.

\section{Mercury intrusion porosimetry}

Mercury porosimetry was applied to determine the porosity and pore sizes of the carrier materials using a porosimeter from Quantachrome (Poremaster 60, Quantachrome Instruments) which evaluates pore diameters in the range of $4 \mathrm{~nm}$ to $200 \mu \mathrm{m}$. Sample size was $0.5 \mathrm{~g}$.

\section{Water adsorption capacity}

For determination of the water adsorption capacity, the dry weight of $20 \mathrm{ml}$ of each carrier material was determined. Subsequently, samples were immersed in water for overnight. The amount of adsorbed water was evaluated by measuring the increase in weight.

\section{Scanning electron microscopy - structural analysis}

The structure of carrier materials without immobilized $P$. ADP cells was characterized by scanning electron microscopy (SEM). Samples were coated with a thin gold layer using a sputter coater (108 Auto Sputter Coater, Cressington) and characterized using Hitachi Tabletop Microscope TM-1000 (Hitachi High Technologies Europe) at a voltage of $15.0 \mathrm{kV}$.

\section{Characterization of immobilized cells}

Immobilized cells were characterized by fluorescence microscopy using Olympus BX60 equipped with a CCD camera (CC-12, Olympus Soft Imaging System). Different bacterial staining kits such as CTC (BacLight ${ }^{\mathrm{TM}}$ RedoxSensor ${ }^{\mathrm{TM}}$ CTC staining reagent, Molecular Probes), SYTO9 and propidium iodide (LIVE/DEAD® Bac Light ${ }^{\mathrm{TM}}$ Bacterial Viability Kit, Molecular Probes) or DAPI (Merck) were used according to the user's manuals.

For electron microscopy imaging, samples were dried at ambient conditions. SEM images of immobilized cells were taken using Phenom Pro-X (LOT-Quantum Design) at an accelerating voltage of $5.0 \mathrm{kV}$. 


\section{Atrazine biodegradation assays}

Atrazine degradation experiments were conducted under nongrowth conditions in BPA-atrazine buffer solution according to Klein et al. ${ }^{34} \mathrm{BPA}$ solution consisted of $20 \mathrm{mM}$ phosphate buffer (PB) and contained $20 \mathrm{mg} \mathrm{l}^{-1}$ atrazine as sole source of carbon and energy.

\section{Biodegradation in initial batch experiments}

For batch tests, $2 \mathrm{~g}$ of immobilized $P$. ADP were cultivated in $30 \mathrm{ml}$ of BPA solution under constant agitation $(100 \mathrm{rpm})$ at room temperature. Samples were taken at predetermined time intervals. Atrazine removal and production of the intermediate hydroxyatrazine was monitored using HPLC and spectrophotometer (see Analytical methods).

After each batch experiment, immobilized cells were washed vigorously with $\mathrm{PB}$. New batch experiments were restarted using fresh BPA solution.

To evaluate adsorptive effects of atrazine by the immobilization matrices, control samples with no biomass were run in BPA solution and sampled over a period of a few days.

\section{Long-term consecutive batch experiments (>one year)}

To evaluate the long-term operation of immobilized cells, extended batch atrazine-degradation assays were carried out consecutively for a period of about one year. $25 \mathrm{~g}$ of expanded clay with immobilized $P$. ADP were placed in a $250 \mathrm{ml}$ Erlenmeyer flask on an orbital shaker at $25{ }^{\circ} \mathrm{C}$ filled with $50 \mathrm{ml}$ of BPA solution. Every 3-5 days samples were transferred to fresh BPA solution. Between each exposition cycle, immobilized cells were washed vigorously with $\mathrm{PB}$ to remove loosely adhering bacteria.

Over a period of 9 months (comprising 58 consecutive batch experiments), the initial and final concentration of atrazine was measured by spectrophotometry and the amount and percentage of atrazine removed was calculated. Furthermore, final ammonia concentration was evaluated by spectrophotometry and compared to the expected stoichiometric ammonia production from the amount of atrazine degraded (referred as $\% \mathrm{NH}_{4}{ }^{+}$recovered).

\section{Evaluation of storage stability of immobilized $P$. ADP}

Aliquots of immobilized bacteria onto scoria were stored within tightly closed screw cap bottles under moist conditions at $4{ }^{\circ} \mathrm{C}$. After 5 months of storage, the atrazine-degradation activity was investigated according to the initial atrazine degradation experiments conducted directly after immobilization. $4 \mathrm{~g}$ of immobilized $P$. ADP were cultivated in $50 \mathrm{ml}$ of BPA solution, and samples for atrazine analysis were taken at specific periods of time for a period of $96 \mathrm{~h}$. Subsequently, immobilized cells were washed with PB and transferred to fresh BPA solution and atrazine degradation was monitored by HPLC analysis.

\section{Biodegradation under fluid flow in column reactors}

The biodegradation activity of atrazine was tested in $80 \mathrm{ml}$ glass columns packed with about $70 \mathrm{~g}$ scoria ( $1.8 \mathrm{~g}$ bdm per $\mathrm{kg}$ ) and $50 \mathrm{~g}$ clay (3.6 g bdm per $\mathrm{kg}$ ). Control column was operated containing only BPA solution. The reactors were operated under non sterile conditions for a period of one month and a temperature of $25{ }^{\circ} \mathrm{C}$. During that time, different experiments were conducted with different volumes (500, 280, 180 and $100 \mathrm{ml}$ ) of BPA solution recirculating in the semi batch reactor at a rate of $2.5 \mathrm{ml} \mathrm{min}{ }^{-1}$. The initial atrazine concentration was about $15 \mathrm{mg} \mathrm{l}^{-1}$. Atrazine degradation and ammonia $\left(\mathrm{NH}_{4}{ }^{+}\right)$ production was measured daily.

\section{Analytical methods}

Atrazine degradation was monitored using high performance liquid chromatography (HPLC) as well as spectrophotometry. Directly after sampling, samples were centrifuged (10 000 $g, 8$ min) to remove cells. The upper phases of the samples were stored in a freezer until analysis by HPLC or spectrophotometry.

HPLC. HPLC analysis was performed according to Vermeulen et $a l .{ }^{36}$ A sample volume of $50 \mu \mathrm{l}$ was injected into Agilent 1200 equipped with a DAD-detector 1200 (Agilent Technologies). The separation was carried out using the Agilent column RP ZORBAX Eclipse XDB C8 $(4.6 \times 150 \mathrm{~mm}$, particle size $5 \mu \mathrm{m})$ at a flow rate of $1 \mathrm{ml} \mathrm{min}^{-1}$. The mobile phase was methanolwater (40:60), with $50 \mathrm{mM}$ ammonia acetate $\mathrm{pH}$ 7.4. To avoid microbial growth in the storage bottle, $3 \mathrm{mM}$ sodium azide were added to the water phase. The UV chromatograms were recorded at $220 \mathrm{~nm}$ using a diode array detector. Identification of the peaks was performed using external standards of atrazine and the degradation intermediate hydroxyatrazine. Standard solutions were made in methanol at concentrations of $0.1 \mathrm{mM}$.

Spectrophotometry. Atrazine concentration was determined photometrically according to García-González et al. ${ }^{37} 1.5 \mathrm{ml}$ of the sample were mixed with $1.5 \mathrm{ml}$ of distilled water. Absorption was measured at $225 \mathrm{~nm}$ within $3 \mathrm{ml}$ UV cuvettes using a UV-mini 1240 spectrophotometer (Shimadzu).

In order to detect ammonia production, dissolved TAN (total ammonia nitrogen) was determined colorimetrically according to Willis et al. ${ }^{38}$ using UV-mini 1240 spectrophotometer (Shimadzu).

\section{Results and discussion}

\section{Characterization of the carrier matrices}

Previous studies showed that the usage of carrier materials possessing high water adsorption capacity increased biocompatibility of sol-gel immobilization within thin silica layers and is beneficial especially for storage out of liquid. ${ }^{19}$ In the present study, two different carrier materials have been investigated: scoria and expanded clay. Scoria is a volcanic rock possessing numerous macroscopic ellipsoidal vesicles. Expanded clays are lightweight ceramic particles produced by firing natural clay to temperatures of $1100-1200{ }^{\circ} \mathrm{C}$ in a rotary kiln. In the heat, the clay is bloated resulting into expanded pellets with a dense shell surrounding a highly porous core. Expanded clay is widely used at hydroponics as it holds water extremely well and transmits it effectively. Furthermore expanded clay is chemically inert and has neutral $\mathrm{pH}$. In the present study, the expanded clay beads were crushed so that the porous core is exposed to the exterior for better immobilization of the microorganisms within that pores. 
As the pore structure of the carrier material is important for its water absorption and holding capacity but also for the efficiency of cell immobilization and subsequent diffusion of nutrients, the pore structure and water holding capacity were investigated. Results of pore structural analysis by mercury intrusion porosimetry are given in Table 1 and Fig. 2. As it is seen from Fig. 2, the major part of pores are in a range of 5-200 $\mu \mathrm{m}$ for expanded clay granules (about $75 \%$ of the total open porosity) and scoria (ca. 65\%), respectively. These pores (pore diameter $>5 \mu \mathrm{m}$ ) should be available for the deposition of the cells within the granules during the immobilization process. However, expanded clay showed a 3 times higher total open pore volume compared to scoria granules.

Pore structure and surface textures of the carrier materials were further observed using scanning electron microscopy (SEM). The SEM micrographs reveal the characteristic pore networks of these carriers (Fig. 1). Scoria possesses macroscopic ellipsoidal vesicles with only minor amounts of micropores (Fig. 1C and D). It appears that there are few interconnections between these pores and the surface of the scoria seems smooth and impervious. By contrast, the surface of crushed expanded clay granules is rough with open porosity characterized by an interpenetrating pore network with large macropores as well as large amounts of micro- and mesopores (Fig. 1A and B). The open porosity of the expanded clay should enable a good fluid flow and nutrient supply of the embedded bacteria. The higher porosity of expanded clay granules further favors the water uptake and storage capability. The water uptake capability of expanded clay and scoria was compared to glass (Table 2). Glass has been widely used as carrier material for sol-gel coatings in previous studies. However, cells demonstrated low viability when coated onto glass. ${ }^{16,39,40}$ Table 2 shows the higher amounts of water that can be taken up by expanded clay and scoria compared to glass.

\section{Characterization of immobilized $P$. ADP cells}

Starting from the cell-silica sol suspension, cells can be either cast into silica hydrogel bodies or coated onto various substrates (e.g., glass, textiles, clay pellets) by conventional deposition techniques such as dip, spin and spray coating, as well as impregnation.

In the present study, expanded clay pellets and scoria were coated by incubation of these carrier materials into neutralized silica nanosol A suspension containing $P$. ADP cells $(5 \mathrm{~g} \mathrm{bdm}$ per l) for about $5 \mathrm{~min}$. Subsequently, the impregnated carrier material was withdrawn from the sol suspension. The remaining cell-sol suspension could further be reused for subsequent

Table 1 Results of mercury intrusion analysis of the pore structure of expanded clay and scoria granules (grain size 1-2 $\mathrm{mm}$ )

\begin{tabular}{lcc}
\hline & Exp. clay & Scoria \\
\hline Sample weight $[\mathrm{g}]$ & 0.5 & 0.5 \\
Sample bulk volume $\left[\mathrm{cm}^{3}\right]$ & 0.64 & 0.5 \\
Surface area $\left[\mathrm{m}^{2} \mathrm{~g}^{-1}\right]$ & 19.6 & 8.1 \\
Total pore volume $\left[\mathrm{cm}^{3}\right]$ & 0.199 & 0.063 \\
Total porosity $[\%]$ & 31.1 & 12.6
\end{tabular}
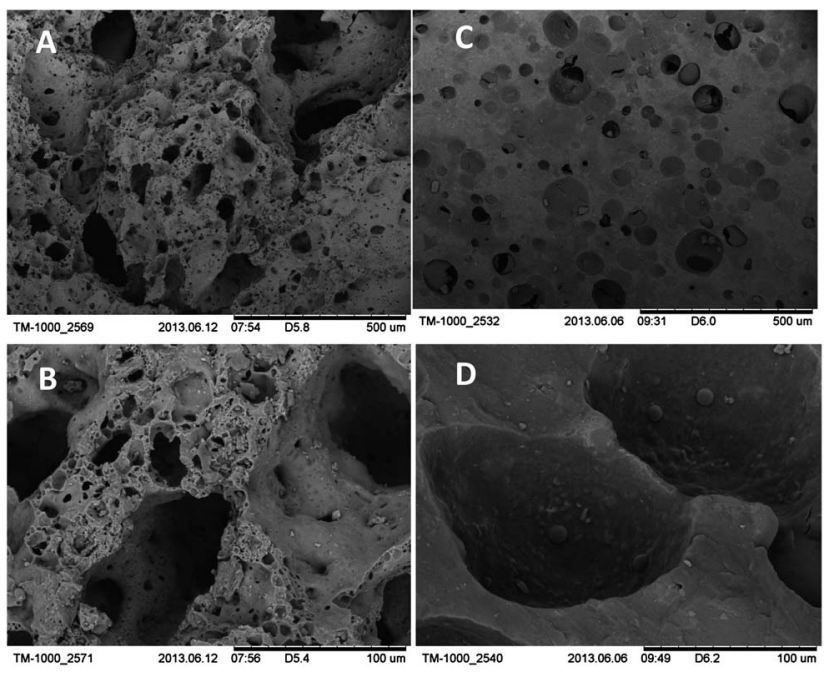

Fig. 1 SEM micrographs of the surface of the micro- and macrostructure of the carrier materials without immobilized $P$. ADP at increasing magnifications: ( $A$ and $B$ ) expanded clay pellets and ( $C$ and D) scoria.

coatings making the coating process very economic. For instance, for coating $80 \mathrm{ml}$ of expanded clay and scoria, samples were impregnated using about $80 \mathrm{ml}$ of cell-sol suspension to ensure full coverage of the carrier materials. However, only
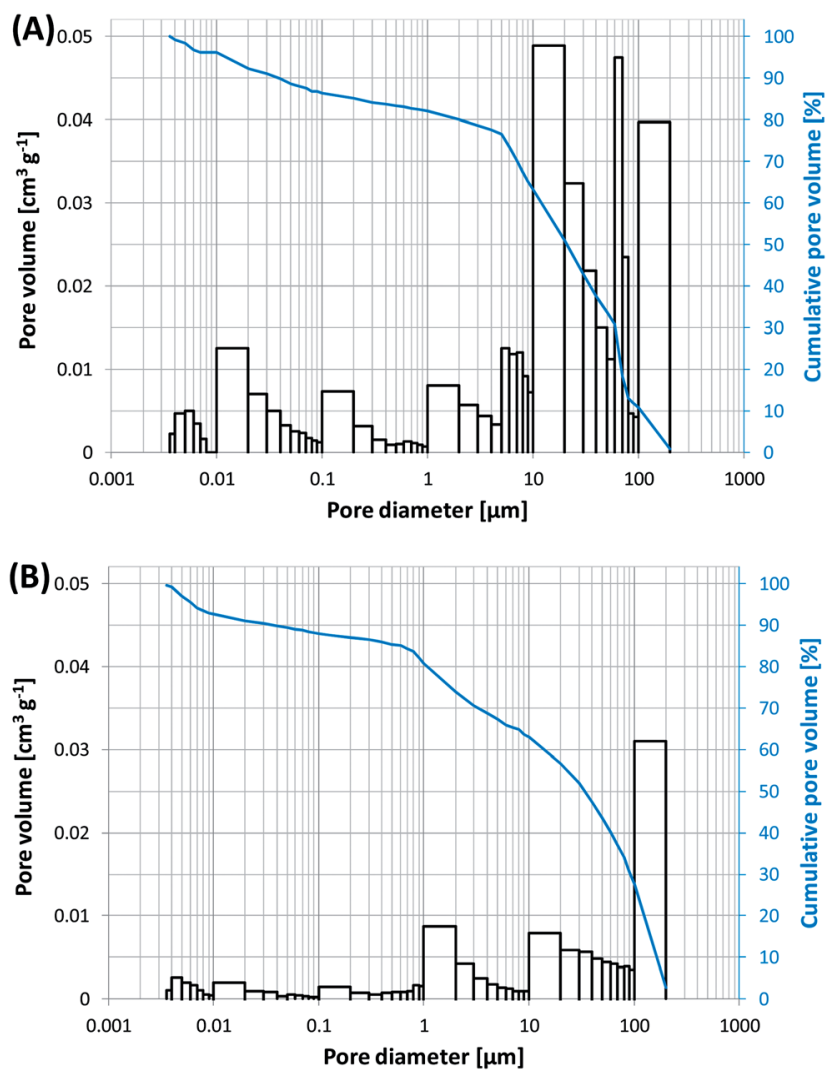

Fig. 2 Pore size distribution (columns) and cumulative pore volume (curves) (A) of expanded clay and (B) of scoria. Note that only open pores can be captured by mercury intrusion porosimetry. 
Table 2 Water adsorption capability of expanded clay, scoria and glass cullet per volume [vol\%] and per weight [wt\%]

\begin{tabular}{lcll}
\hline & Exp. clay & Scoria & \multicolumn{1}{l}{ Glass } \\
\hline Sample volume [ml] & 20 & 20 & 20 \\
Sample weight [g] & $8.5 \pm 0.2$ & $18.7 \pm 0.3$ & $26.4 \pm 0.2$ \\
Adsorbed water [vol\%] & $23.8 \pm 1.3$ & $19.8 \pm 1.3$ & $9.0 \pm 1.7$ \\
Adsorbed water [wt\%] & $55.2 \pm 1.3$ & $21.2 \pm 1.5$ & $6.9 \pm 1.2$
\end{tabular}

about $32 \mathrm{ml}$ of the cell-sol suspension were absorbed by expanded clay and $26 \mathrm{ml}$ by scoria. With the remaining cell-sol suspension further coatings could be successively conducted.

After gelation of the deposited film, cells are firmly embedded within thin silica layers at the surface and within the pores of the carriers. Microscopic studies by SEM imaging and fluorescence microscopy showed that cells were evenly distributed within the silica hydrogel film (Fig. 3). Silica layer thickness has been estimated to be about $2-10 \mu \mathrm{m}$.

As samples were simply dried at ambient conditions for SEM imaging, relevant volume contraction and crack formation were observed upon sample preparation (Fig. 3A and B). The high shrinkage and contraction of the silica hydrogel film during sample preparation point out the necessity of preservation of humidity of the immobilization matrix. In that way samples have been stored and handled under wet atmosphere for further experiments.

Bacterial distribution has further been studied in wet state using never dried samples. Immobilized cells have been visualized using fluorescent dyes. Fluorescence microscopy using
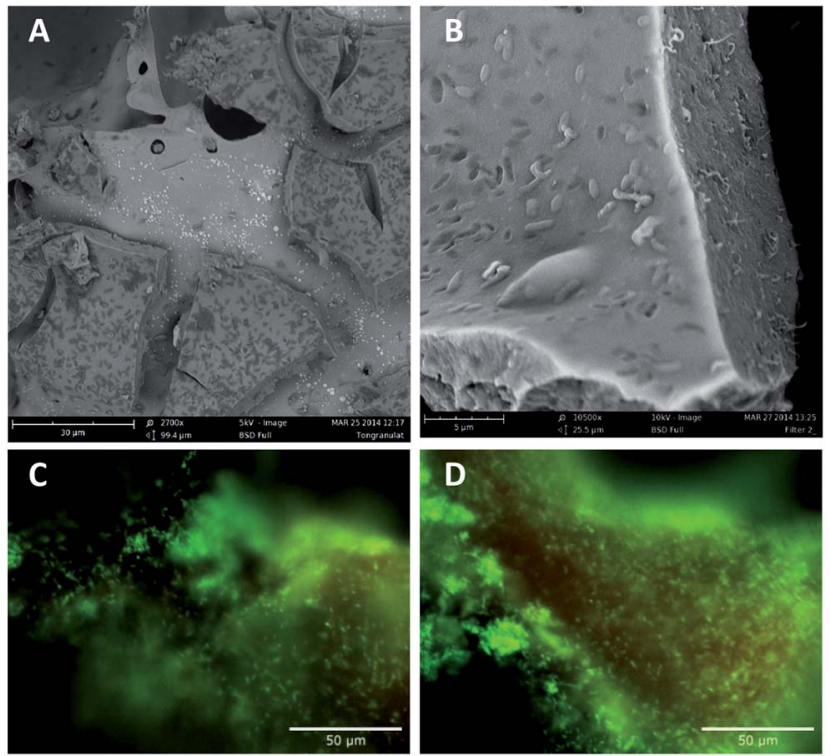

Fig. 3 (A and B) SEM images of P. ADP immobilized within thin silica layers onto expanded clay. Cracks of the silica layer are due to drying of the sample prior to SEM imaging. (C and D) Fluorescence images of cells immobilized onto scoria. Cells were visualized by Syto 9 green and propidium iodide staining. Green fluorescent cells are viable, whereas red fluorescent cells have a compromised cell membrane and are dead. Images were obtained directly after immobilization with no previous drying. Filter characteristics: Ex.: 460-490 nm; Em. > 520 nm. live/dead staining revealed that the major part of the immobilized cells is homogeneously distributed at the surface of the carrier materials and did survive the immobilization procedure. Fig. 3C and D shows fluorescence images of cells immobilized onto scoria. Images for cells immobilized onto expanded clays are not shown, as the fluorescent dyes were strongly adsorbed by the clay resulting in strong background fluorescence.

\section{Atrazine removal by the immobilization matrix}

To evaluate adsorptive effects of atrazine by the immobilization matrix itself, samples of the immobilization matrix containing no bacteria were run as controls in parallel to batch tests. They were incubated in atrazine buffer solution, and atrazine removal was monitored by HPLC measurements (see Fig. 4). The results indicate that atrazine does adsorb to the TEOS-derived silica matrices even though only to a minor extent. No degradation intermediates of atrazine were found indicating adsorptive effects by the immobilization matrices rather than degradation.

After $48 \mathrm{~h}$ of incubation, $7 \%$ and $11 \%$ of the initial atrazine was removed by expanded clay coated by silica nanosol A and silica hydrogels derived from silica nanosol B, respectively.

In total, $0.7 \pm 0.01 \mathrm{mg}$ atrazine per gram expanded clay and $1.1 \pm 0.05 \mathrm{mg}$ per gram silica hydrogel were absorbed by the carrier materials containing no cells. This finding is in accordance to Reátegui et al., ${ }^{41}$ who observed atrazine adsorption to TMOS-derived silica matrices.

As atrazine adsorption by the immobilization matrix did only account for a minor part of the atrazine removal, atrazine removal by adsorptive effects is not taken into account for the following experiments.

\section{Atrazine removal by biodegradation in initial batch experiments}

The ability of sol-gel immobilized $P$. ADP to degrade atrazine was investigated in batch experiments immediately after immobilization under non-growth conditions in phosphate buffer $(20 \mathrm{mM})$ containing only atrazine (about $20 \mathrm{mg} \mathrm{l}^{-1}$ ).

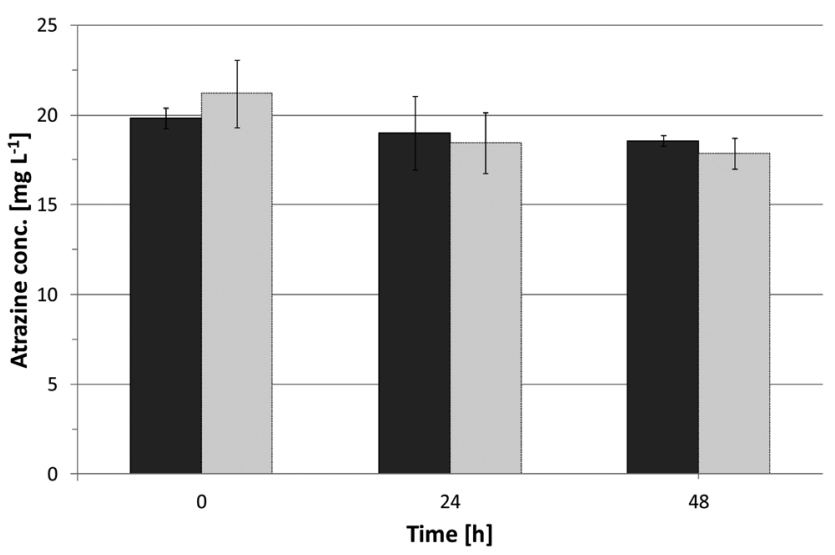

Fig. 4 Atrazine removal by the immobilization matrix containing no bacteria: ( $\square$ ) silica hydrogels, and ( $\square$ ) silica coated onto expanded clay. $2 \mathrm{~g}$ of the carriers were incubated in $30 \mathrm{ml}$ BPA containing $20 \mathrm{mg} \mathrm{l}^{-1}$ atrazine. Concentrations were determined from HPLC peak area. 
During the initial batch experiments, turbidity in the medium was observed caused by the detachment of silica gel particles and released biomass. This finding was more pronounced for cells immobilized within silica gels.

Atrazine degradation and production of hydroxyatrazine intermediate were monitored by HPLC measurements. Furthermore, the production of ammonia was determined by spectrophotometry (total ammonia nitrogen).

Fig. 5 shows atrazine removal and production of ammonia, in a 24 hour batch experiment conducted with $P$. ADP immobilized within silica hydrogels as well as within thin silica layer coated onto expanded clay pellets. Atrazine was rapidly removed. Biodegradation of atrazine was faster for cells immobilized within silica hydrogels. This may be due to the higher cell release observed for these samples but also to the higher bacterial loading of the silica hydrogels. HPLC analysis showed that hydroxyatrazine gradually appeared after $1 \mathrm{~h}$, in both samples (data not shown). Determination of total ammonia nitrogen (Fig. 5, dotted lines) revealed an elevated initial concentration of ammonia for both samples that cannot be accounted to the biodegradation of atrazine.

The high concentration might have been created by a lysis of cells in the silica matrix. After further consecutive batches, excess concentrations of ammonia decreased as the immobilized cells were washed between batches and transferred to fresh atrazine buffer solution. After 5 batches, ammonia concentrations consistent to the breakdown of atrazine were recovered and no turbidity was observed.

During the first batch experiment carried out directly after cell immobilization, atrazine was completely removed from the treated atrazine buffer solution within the $24 \mathrm{~h}$ experiment. However, in subsequent batch experiments, atrazine was not fully metabolized by immobilized $P$. ADP regardless of the immobilization method. In the course of seven successive

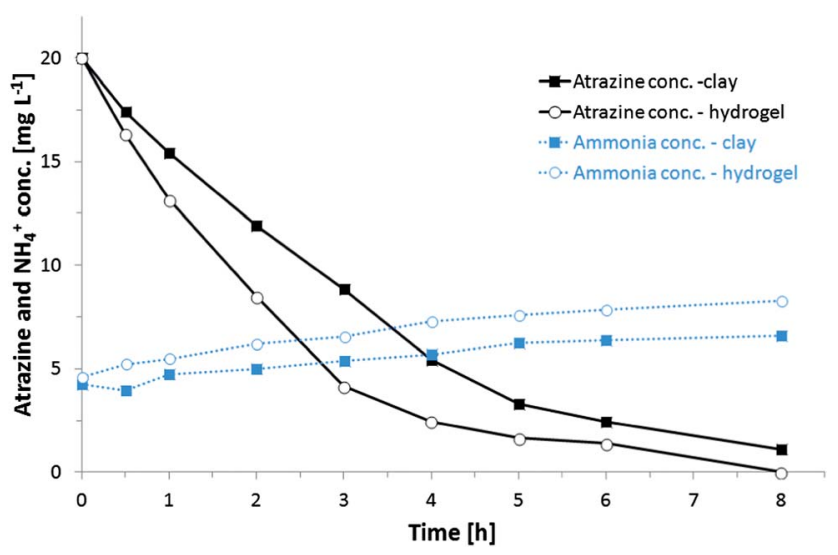

Fig. 5 Atrazine removal (continuous lines) and production of ammonia $\mathrm{NH}_{4}{ }^{+}$(dotted lines) by $\mathrm{P}$. ADP immobilized within $2 \mathrm{~g}$ of silica hydrogel (open circles) and within thin silica layers coated onto $2 \mathrm{~g}$ of expanded clay (squares). Initial batch tests were run directly after immobilization. Atrazine concentration was determined from HPLC peak area. Total ammonia nitrogen was determined by spectrophotometry. Experiments were run under non-growths conditions in PB containing atrazine as sole source of carbon and nitrogen. batches following the initial batch experiment, an average of $88 \%$ and $85 \%$ of the initial atrazine was degraded by $P$. ADP immobilized onto expanded clay and within silica hydrogels, respectively. A drop in atrazine degradation ability over time was also found for $P$. ADP immobilized within electrospun microfibers by Klein et al. ${ }^{34}$ They assigned the decline as a result of deterioration of the stability of enzymes as a similar reduction in atrazine removal was observed with pure atrazine chlorohydrolase (AtzA), the first enzyme in the atrazine degradation pathway, entrapped in silica hydrogels by Kauffmann and Mandelbaum. ${ }^{42}$

To further investigate, the long-term capability of sol-gel immobilized $P$. ADP, extended consecutive batch experiments were carried out (see next section). However, experiments were run only for $P$. ADP immobilized onto expanded clay due to the poor mechanical strength of the silica hydrogels. During first batch experiments, silica hydrogels were observed to breakdown into smaller pieces and finally disintegrate, whereas silica coated expanded clay particles remained stable.

\section{Long-term consecutive batch experiments (>one year)}

For atrazine degradation cell viability is not necessarily required since atrazine is dechlorinated by a single hydrolytic enzyme (atrazine chlorohydrolase AtzA) ${ }^{43}$ to yield non-hazardous hydroxyatrazine. In that way, purified AtzA enzyme obtained from $P . \mathrm{ADP}^{\mathbf{4 2 , 4 4}}$ as well as non-viable Escherichia coli cells expressing AtzA ${ }^{\mathbf{4 1}}$ have been previously immobilized in silica gels for atrazine biodegradation. Immobilizing whole cells of $E$. coli in contrast to purified enzymes improved significantly the long-term operational activity of the encapsulated enzyme. The enzyme remained fully active and atrazine was continuously degraded for a period of more than 4 months even though cells were non-viable. In contrast, immobilized $P$. ADP cells were reported to require viability for efficient atrazine degradation. ${ }^{\mathbf{4 5}}$

In order to evaluate the potential for continuous operation of sol-gel immobilized $P$. ADP, repeated-batch degradation assays were carried out over a period of more than one year under nongrowth conditions and cell vitality was checked after that period of time. Cells immobilized onto expanded clay were weekly transferred to fresh atrazine buffer solution (BPA).

Samples were washed rigorously between each assay cycle to remove free bacteria. Over a period of 270 days (comprising 58 consecutive batch experiments), the initial and final concentration of atrazine were measured by spectrophotometry, and the amount and percentage of atrazine removed was calculated. Furthermore, final ammonia concentration was measured and compared to the expected stoichiometric ammonia production from the amount of atrazine degraded $\left(\% \mathrm{NH}_{4}{ }^{+}\right.$recovered). The average values and standard deviations are listed in the Table 3. The results demonstrate that $P$. ADP embedded within thin silica layers onto expanded clay remained active in degrading atrazine over a long time scale (>one year) - even though experiments were conducted under non-growth conditions with atrazine as sole source of carbon and nitrogen. High atrazine removal was obtained with about $93 \%$ of atrazine removed in average. After one year consecutive atrazine degradation, 
Table 3 Results of extended consecutive batch tests for atrazine biodegradation using $P$. ADP immobilized onto expanded clay. Experiments were run under non-growths conditions in PB containing atrazine as sole of carbon and nitrogen over a period of one year

\begin{tabular}{lc}
\hline & \multicolumn{1}{c}{ Average } \\
\hline No. of batches & \multicolumn{1}{c}{} \\
Day per batch & 38 \\
Initial atrazine conc. $\left[\mathrm{mg} \mathrm{l}^{-1}\right]$ & $20.4 \pm 1.1$ \\
Final atrazine conc. $\left[\mathrm{mg} \mathrm{l}^{-1}\right]$ & $1.3 \pm 1.0$ \\
Final $\mathrm{NH}_{4}{ }^{+}$conc. $\left[\mathrm{mg} \mathrm{l}^{-1}\right]$ & $4.7 \pm 0.8$ \\
$\%$ Atrazine removed & $93.4 \pm 4.8$ \\
$\% \mathrm{NH}_{4}{ }^{+}$recovered & $77.3 \pm 13.8$
\end{tabular}

viability and respiratory activity of immobilized cells were checked by CTC staining revealing activity of the majority of embedded cells.

\section{Atrazine removal under fluid flow in column reactors}

In order to evaluate the performance and stability of sol-gel immobilized $P$. ADP under fluid flow, flow-dynamic studies were carried out in a bench-scale column reactor packed with either coated expanded clay or scoria. After immobilization, carrier materials were washed once in $\mathrm{PB}$ to remove excess biomass and silica gel. Samples were placed in $80 \mathrm{ml}$ glass columns for semi-batch experiment. Each column was fed with atrazine buffer solution which was recirculated. Experiments were run for about one month at a recirculation rate of $2.5 \mathrm{ml}$ $\mathrm{min}^{-1}$. During first assays ( $500 \mathrm{ml}$ batch volume) the removal of atrazine was very low. For that reason, it was decided to decrease the batch volume. The time curves of atrazine degradation and calculated atrazine removal rates are presented in Fig. 6 . The volumes of the atrazine solution recirculated in the columns were $100 \mathrm{ml}$ (Fig. 6A) and $280 \mathrm{ml}$ (Fig. 6B), respectively. In principal, cells immobilized onto expanded clay and scoria showed similar capacity for atrazine degradation.

In the experiment carried out circulating $100 \mathrm{ml}$ (Fig. 6A), the initial removal rate was higher for scoria samples $\left(0.5 \mathrm{mg} \mathrm{h}^{-1}\right)$ compared to expanded clay $\left(0.22 \mathrm{mg} \mathrm{h}^{-1}\right)$. But after one hour, both samples maintained almost the same removal rates ranging between $0.1-0.2 \mathrm{mg} \mathrm{h}^{-1}$.

In a $280 \mathrm{ml}$ experiment that was done over $28 \mathrm{~h}$ (Fig. 6B), it is possible to see the correlation between the atrazine removal rate to its concentration. As the amount of atrazine decreased the removal rate also declined. Atrazine degradation rate is known to be correlated to the atrazine concentration in the bulk. ${ }^{27}$ The removal rate declined and reached 0 over time. Atrazine degradation stopped - even though there was still atrazine left in solution. After about $80-90 \%$ of the atrazine was removed, no further atrazine was degraded as already observed within the initial batch experiments.

Due to the elevated porosity of the carrier materials and the thin silica layer coating, atrazine should be readily accessible to immobilized $P$. ADP, and the removal rate should not be strongly affected by diffusion problems compared to immobilization within thicker matrices and hydrogel bodies.
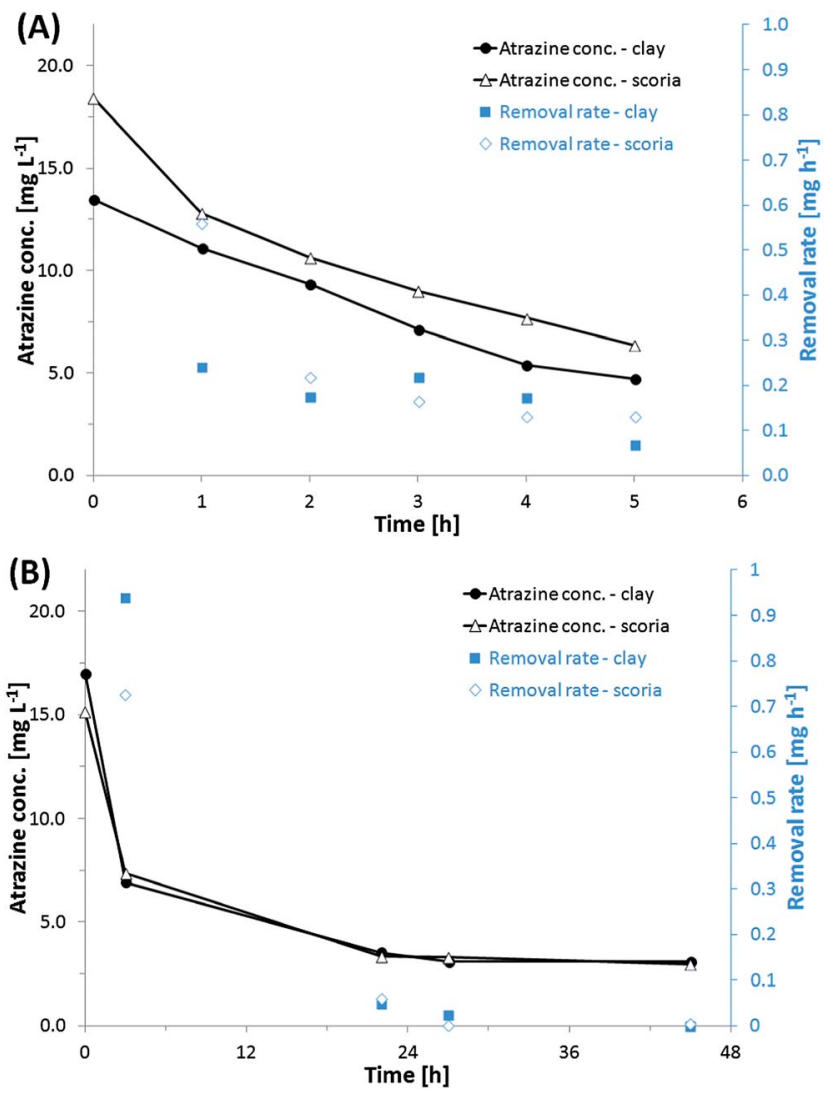

Fig. 6 Time curses of atrazine degradation and removal rates of $P$. ADP immobilized onto expanded clay and scoria under fluid flow in 80 $\mathrm{ml}$ columns with (A) $100 \mathrm{ml}$ of atrazine buffer solution recirculating over a period of $6 \mathrm{~h}$ and (B) $280 \mathrm{ml}$ recirculating for $45 \mathrm{~h}$.

\section{Evaluation of degradation activity after storage}

When the viability of embedded cells has to be maintained, the applicability of thin silica layers is often limited by the poor storage stability. Cells within thin silica layers are susceptible to fast drying-out, due to the small layer thickness. It has been shown that it is favorable to immerse cells immobilized by solgel coating as fast as possible in aqueous liquids after gelation. ${ }^{10,16,46,47}$ However, being able to handle and store immobilized cells out of liquid would significantly simplify handling and reduce cost for storage and transport for large amount of immobilized cells.

In previous studies, the bacterial strain A. tertiaricarbonis showed surpassing storage stability under humid conditions when immobilized onto expanded clay using the same immobilization procedure as in the present study. ${ }^{19}$ To preserve cell viability, cells have to be maintained in a humid state. Therefore, $P$. ADP immobilized onto scoria was stored at $4{ }^{\circ} \mathrm{C}$ under moist atmosphere. After 5 months of storage, cells were subjected to atrazine degradation, and the results were compared to the results of initial batch experiments conducted directly after immobilization (Fig. 7). It can be seen that immobilized cells were still able to degrade atrazine. However, the degradation rate was significantly reduced compared to starting conditions. Atrazine removal can be assigned to biodegradation 


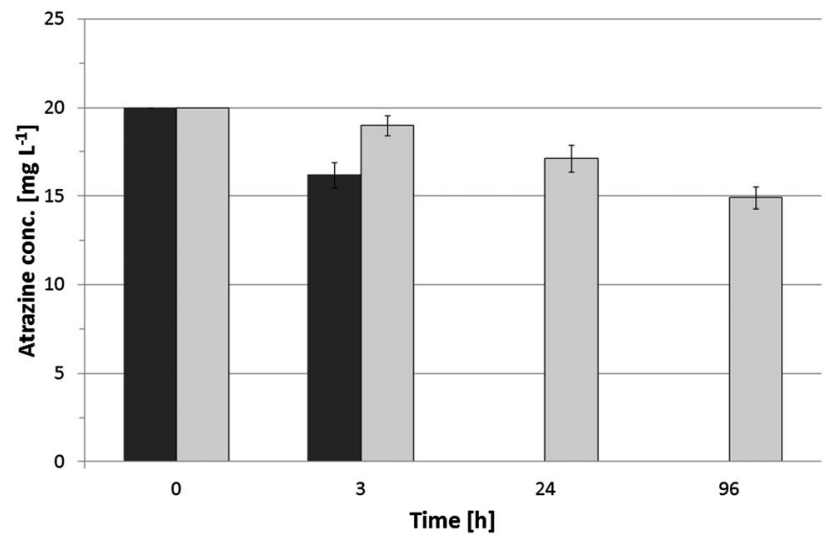

Fig. 7 Atrazine removal by $P$. ADP immobilized within thin silica layers onto scoria. Degradation capacity was monitored $(\square)$ directly after immobilization as well as ( () after 5 months of storage at $4{ }^{\circ} \mathrm{C}$.

as the intermediate hydroxyatrazine was detected (data not shown). After $96 \mathrm{~h}$, about $75 \%$ of the initial atrazine was still remaining in the BPA solution. Samples were washed and subjected to a second run of atrazine degradation. The second run confirmed that the cells were able to degrade atrazine as there was the same slight decrease within $24 \mathrm{~h}$ and the appearance of the degradation product hydroxyatrazine (data not shown). Nevertheless the activity remained low compared to the initial batch experiment. Reasons for loss of activity could be cell death and slow reactivation of cell activity as only nongrowth conditions were applied to the cells (only phosphate buffer containing atrazine; no complex medium).

The bacterial strain used in the present study has been previously immobilized within silica hydrogel bodies by RiettiShati et $a l .{ }^{45}$ They demonstrated atrazine degradation. However, after storage for about 2.5 months at $4{ }^{\circ} \mathrm{C}$, sol-gel entrapped $P$. ADP showed no atrazine degradation and could not be revitalized.

In that way, also atrazine degradation rate was much lower after 5 month of storage compared to starting conditions; results of the present study are still promising, indicating that cells immobilized within thin silica layers onto water-retaining carriers remained vital over storage out of liquid.

\section{Conclusions}

Pseudomonas sp. ADP is one of the fastest atrazine-degrading bacterial strains and capable of metabolizing atrazine at high concentrations, ${ }^{25}$ making this strain particularly interesting for treating industrial effluents from atrazine producing plants. One of the major advantages of $P$. ADP is that that bacterial strain is capable to degrade atrazine under non-growth conditions. This fact simplifies effluent post treatment (no addition of external carbon source necessary) as well as considerably reduces biomass growth and sludge disposal.

The aim of this study was to develop a biohybrid material demonstrating long-term viability and activity of the embedded $P$. ADP cells during storage and especially during application under non-growth conditions (cultivation in buffer solution containing only atrazine as sole source of carbon and nitrogen). The bacterial strain $P$. ADP was immobilized within thin silica layers coated onto water-retaining carrier materials usually used at hydroponics. Due to the high porosity of the carriers and the fact that cells were immobilized within thin silica layers, cells were easily accessible to external reagents and minor diffusion limits should occur compared to immobilization within thick hydrogel bodies.

$P$. ADP cells immobilized onto expanded clay granules remained active in degrading atrazine and showed very high removal rates for at least one year. Cells maintained viability under non-growth conditions. There was no need of addition of an external electron donor.

The results of this study provide a promising basis for the application of sol-gel immobilized bacteria on porous carrier materials for the removal of atrazine from contaminated water. Extended flow dynamic studies as well as operation under field conditions using real contaminated water have to be carried out to evaluate the performance of the sol-gel immobilized bacteria under real-life applications.

\section{Acknowledgements}

This study was partially supported by grants from German Federal Ministry of Education and Research (BMBF) and from the Israeli Ministry of Sciences and Arts (MOST) (German-Israeli Water Technology Research Fund, Grant no. WT1103/ 02WA1223), as well as by the BMBF-MOST Young Scientist Exchange Program (YSEP76). The authors further would like to thank Carsten Pape from LOT-QuantumDesign for SEM imaging of $P$. ADP immobilized within thin silica layers onto expanded clay pellets.

\section{Notes and references}

1 C. Depagne, C. Roux and T. Coradin, Anal. Bioanal. Chem., 2011, 400(4), 965-976.

2 F. H. Dickey, J. Phys. Chem., 1955, 59(8), 695.

3 M. Glad, O. Norrlöw, B. Sellergren, N. Siegbahn and K. Mosbach, J. Chromatogr. A, 1985, 347, 11.

4 G. Carturan, R. Campostrini, S. Dirè, V. Scardi and E. de Alteriis, J. Mol. Catal., 1989, 57, 13.

5 S. Braun, S. Rappoport, R. Zusman, D. Avnir and M. Ottolenghi, Mater. Lett., 1990, 10(1-2), 1.

6 D. Avnir, Acc. Chem. Res., 1995, 28(8), 328.

7 D. Avnir, T. Coradin, O. Lev and J. Livage, J. Mater. Chem., 2006, 16(11), 1013.

8 C. J. Brinker and G. W. Scherer, Sol-gel science: The physics and chemistry of sol-gel processing, Academic Press, Boston, 1990.

9 J. Livage, T. Coradin and C. Roux, J. Phys.: Condens. Matter, 2001, 13(33), R673.

10 N. Nassif, A. Coiffier, T. Coradin, C. Roux, J. Livage and O. Bouvet, J. Sol-Gel Sci. Technol., 2003, 26(1), 1141.

11 H. Böttcher, U. Soltmann, M. Mertig and W. Pompe, J. Mater. Chem., 2004, 14, 2176. 
12 T. Coradin, J. Allouche, M. Boissiere and J. Livage, Curr. Nanosci., 2006, 2, 219.

13 S. Gadre and P. I. Gouma, J. Am. Ceram. Soc., 2006, 89, 2987.

14 T. Coradin, M. Amoura, C. Roux, J. Livage and M. C. Flickinger, Biocers, Industrial Applications: Encyclopedia of Industrial Biotechnology, John Wiley \& Sons, Inc., 2009.

15 C. F. Meunier, P. Dandoy and B.-L. Su, J. Colloid Interface Sci., 2010, 342(2), 211.

16 G. Kuncova, O. Podrazky, S. Ripp, J. Trögl, G. S. Sayler, K. Demnerova and R. Vankova, J. Sol-Gel Sci. Technol., 2004, 31(1), 335.

17 M. Perullini, M. Jobbagy, M. Bermudez Moretti, S. Correa Garcia and S. A. Bilmes, Chem. Mater., 2008, 20(9), 3015.

18 M. L. Ferrer, Z. Y. Garcia-Carvajal, L. Yuste, F. Rojo and F. del Monte, Chem. Mater., 2006, 18(6), 1458.

19 A. Pannier, C. Oehm, A. R. Fischer, P. Werner, U. Soltmann and H. Böttcher, Enzyme Microb. Technol., 2010, 47(6), 291.

20 M. Graymore, F. Stagnitti and G. Allinson, Environ. Int., 2001, 26(7-8), 483.

21 E. C. Directive, Off. J. Eur. Communities: Legis., 1998, 330, 5. 22 M. F. Desimone, G. S. Alvarez, M. L. Foglia and L. E. Diaz, Recent Pat. Biotechnol., 2009, 3, 55.

23 F. J. Beltran, J. F. García-Araya and B. Acedo, Water Res., 1994, 28(10), 2153.

24 N. W. Brown, E. P. L. Roberts, A. Chasiotis, T. Cherdron and N. Sanghrajka, Water Res., 2004, 38(13), 3067.

25 R. Mandelbaum, D. Allan and L. Wackett, Appl. Environ. Microbiol., 1995, 61(4), 1451.

26 J. J. Crawford, G. K. Sims, R. L. Mulvaney and M. Radosevich, Appl. Microbiol. Biotechnol., 1998, 49(5), 618-623.

27 I. Katz, C. G. Dosoretz, R. T. Mandelbaum and M. Green, Water Res., 2001, 35(13), 3272.

28 S. Siripattanakul, W. Wirojanagud, J. M. McEvoy, F. X. M. Casey and E. Khan, Chemosphere, 2009, 74(2), 308.

29 M. B. Cassidy, H. Lee and J. T. Trevors, J. Ind. Microbiol. Biotechnol., 1996, 16(2), 79.
30 J. Tampion and M. D. Tampion, Immobilized cells: Principles and applications, Cambridge Univ. Pr., Cambridge, 1987.

31 Immobilization of Enzymes and Cells, ed. J. M. Guisan, Humana Press, Totowa, USA, 2006.

32 L. Zhou, G. Li, T. An, J. Fu and G. Sheng, Recent Pat. Eng., 2008, 2, 28.

33 A. Leonard, P. Dandoy, E. Danloy, G. Leroux, C. F. Meunier, J. C. Rooke and B.-L. Su, Chem. Soc. Rev., 2011, 40(2), 860.

34 S. Klein, R. Avrahami, E. Zussman, M. Beliavski, S. Tarre and M. Green, J. Ind. Microbiol. Biotechnol., 2012, 39(11), 16051613.

35 R. Mandelbaum, L. Wackett and D. Allan, Appl. Environ. Microbiol., 1993, 59(6), 1695.

36 N. M. J. Vermeulen, Z. Apostolides, D. J. J. Potgieter, P. C. Nel and N. S. H. Smit, J. Chromatogr. A, 1982, 240(1), 247.

37 V. García-González, F. Govantes, L. J. Shaw, R. G. Burns and E. Santero, Appl. Environ. Microbiol., 2003, 69(12), 6987.

38 R. B. Willis, M. E. Montgomery and P. R. Allen, J. Agric. Food Chem., 1996, 44(7), 1804.

39 D. Fiedler, A. Thron, U. Soltmann and H. Böttcher, Chem. Mater., 2004, 16(16), 3040.

40 S. Matys, J. Raff, U. Soltmann, S. Selenska-Pobell, H. Böttcher and W. Pompe, Chem. Mater., 2004, 16(26), 5549.

41 E. Reátegui, E. Reynolds, L. Kasinkas, A. Aggarwal, M. Sadowsky, A. Aksan and L. Wackett, Appl. Microbiol. Biotechnol., 2012, 96(1), 231-240.

42 C. Kauffmann and R. T. Mandelbaum, J. Biotechnol., 1998, 62(3), 169.

43 M. L. de Souza, M. J. Sadowsky and L. P. Wackett, J. Bacteriol., 1996, 178(16), 4894.

44 C. G. Kauffmann and R. T. Mandelbaum, Environ. Biotechnol., 1996, 51(3), 219.

45 M. Rietti-Shati, D. Ronen and R. T. Mandelbaum, J. Sol-Gel Sci. Technol., 1996, 7(1), 77.

46 A. Coiffier, T. Coradin, C. Roux, O. M. M. Bouvet and J. Livage, J. Mater. Chem., 2001, 11(8), 2039.

47 J. R. Premkumar, E. Sagi, R. Rozen, S. Belkin, A. D. Modestov and O. Lev, Chem. Mater., 2002, 14(6), 2676. 